\title{
Students' Errors Analysis in Solving Problems in the Material of Sequences and Series based on Hadar's Criteria in terms of Students' Mathematical Understanding
}

\author{
Ilham Minggi*, Bernard, \& Aco Fauzan \\ Department of Mathematics, Universitas Negeri Makassar, Makassar, Sulawesi Selatan, Indonesia
}

\begin{abstract}
This study aims to describe students' errors in solving problems in the material of Sequences and Series based on Hadar's criteria in terms of students' mathematical understanding. The type of research used is qualitative research with a descriptive approach. There are 6 research subjects, namely 2 students with high mathematical understanding, 2 students with moderate mathematical understanding, and 2 students with low mathematical understanding. The instrument used in data collection was an understanding test containing 7 questions, a series and series problem test containing 3 questions, as well as interview guidelines. The results showed that all subjects who worked on questions related to determining the P-th term in the series geometry and in working on problems related to determining the cattle population tend to make technical errors. Meanwhile, in working on problems related to determining the number of terms in an arithmetic sequence, the subject did not experience any errors in completing the answer except for the fifth subject and the sixth subject who did not answer at all.
\end{abstract}

\section{Introduction}

Siswa pada umumnya menghadapi banyak permasalahan dalam mengerjakan berbagai bentuk soal matematika. Permasalahan dalam kehidupan sehari-hari yang terkait dengan pemecahan masalah matematika biasanya dituangkan dalam soal cerita. Akan tetapi, menyelesaikan soal cerita merupakan aspek yang sulit dilakukan oleh siswa karena siswa harus terlebih dahulu memahami isi soal cerita, setelah itu menarik kesimpulan dan memisalkannya dengan simbol-simbol matematika. Dalam menyelesaikan soal cerita diperlukan pemahaman konsep yang baik, namun hingga saat ini pemahaman siswa dalam menyelesaikan soal cerita matematika masih cukup rendah sehingga kesalahankesalahan dalam menyelesaikan soal cerita matematika juga tidak dapat terhindarkan (Nurfahmi, 2018).

Pemberian soal cerita dimaksudkan untuk melatih pemahaman siswa dalam menyelesaikan masalah matematika. Pemahaman matematika adalah pengetahuan dan keterampilan dasar yang diperlukan untuk dapat melakukan manipulasi matematika meliputi pemahaman konsep dan pengetahuan prosedural. Pemahaman matematika adalah salah satu tujuan penting dalam pembelajaran, memberikan pengertian bahwa materi-materi yang diajarkan kepada siswa bukan hanya sebagai hafalan, namun lebih dari itu dengan pemahaman siswa dapat lebih mengerti akan konsep materi pelajaran itu sendiri (Depdiknas, 2006).

Pokok bahasan matematika yang sukar untuk dikuasai oleh siswa adalah topik Barisan dan Deret. Barisan dan deret merupakan salah satu materi pelajaran matematika yang dipelajari oleh siswa di bangku SMA sederajat. Pada materi barisan dan deret, kebanyakan siswa kesulitan dalam menafsirkan dan memahami soal cerita sehingga menyebabkan kesalahan dalam perhitungan dan penyelesaian akhir (Nurfahmi, 2018).

Penelitian oleh Widyatari (2017) menunjukkan bahwa kesalahan yang dilakukan oleh siswa dengan pemahaman tinggi, sedang dan rendah adalah salah dalam menentukan rumus yang akan digunakan untuk menyelesaikan masalah. Kemudian sejalan dengan hasil penelitian oleh Handayani (2020) bahwa kesalahan yang dilakukan siswa yaitu

\footnotetext{
* Corresponding author.

E-mail address: xxxx@xxxxxx.edu (Fullname of corresponding author)
} 
kesalahan konsep, kesalahan menggunakan data, kesalahan interpretasi bahasa, kesalahan teknis dan kesalahan penarikan kesimpulan.

Dalam penelitian ini, kesalahan siswa yang dianalisis berupa kesalahan yang diberikan oleh Hadar, Zaslavsky dan Inbar (1987) yang terdiri dari enam kesalahan, yaitu (1) kesalahan menggunakan data, (2) kesalahan menggunakan bahasa, (3) kesalahan menggunakan logika untuk menarik kesimpulan, (4) kesalahan menggunakan definisi atau teorema, (5) penyelesaian tidak diperiksa kembali dan (6) kesalahan teknis. Adapun klasifikasi jenis kesalahan menurut Hadar yaitu kesalahan data, kesalahan menginterpretasikan bahasa, kesalahan menggunakan definisi atau teorema, penyelesaian tidak diperiksa kembali dan kesalahan teknis (Anwar \& Hidayani, 2020)

Penelitian ini menitik beratkan pada kesalahan siswa dalam menyelesaikan soal matematika. Penelitian ini bertujuan untuk mendeskripsikan kesalahan siswa dalam menyelesaikan masalah materi Barisan dan Deret berdasarkan kriteria Hadar ditinjau dari pemahaman matematika siswa kelas XII SMA.

\section{Literature Review}

Kesalahan adalah suatu bentuk peyimpangan terhadap jawaban yang sebenarnya yang bersifat sistematis (Rahmawati, 2018). Kesalahan-kesalahan siswa perlu dianalisis untuk mengetahui jenis kesalahan yang dilakukan siswa. Melalui analisis kesalahan, diperoleh jenis dan letak kesalahan yang dilakukan siswa, sehingga guru dapat memberikan jenis bantuan yang tepat kepada siswa (Gusman, 2021).

Menurut Hadar, et.al. (1987) terdapat 6 jenis kesalahan yang sering dilakukan siswa, yaitu: Kesalahan menggunakan data, kesalahan menggunakan bahasa, kesalahan menggunakan logika untuk menarik kesimpulan, kesalahan menggunakan definisi atau teorema, penyelesaian tidak diperiksa kembali dan kesalahan teknis. Elizabeth (2016) menjelaskan keenam jenis kesalahan hadar tersebut:

1) Kesalahan menggunakan data

Kesalahan yang biasa terjadi pada kategori ini yaitu ketidaksesuaian siswa pada saat menggunakan data dari yang diketahui dengan yang ditangkap siswa. Karakteristik yang meliputi kesalahan data yaitu (1) kurang tepatnya siswa menyalin data dari soal, (2) siswa menambahkan data-data yang tidak sesuai, (3) mengabaikan data yang diberikan, (4) menyatakan suatu syarat yang tidak dibutuhkan, (5) mengartikan informasi tidak sesuai dengan teks sebenarnya, (6) mengganti syarat yang ditentukan dengan informasi lain yang tidak sesuai dan (7) menggunakan nilai suatu variabel untuk variabel lain.

2) Kesalahan menggunakan bahasa

Karakteristik yang meliputi kesalahan ini ialah (1) kesalahan siswa mengartikan simbol matematika ke dalam bahasa sehari-hari, (2) menulis simbol dari suatu konsep dengan simbol lain yang artinya berbeda.

3) Kesalahan menggunakan logika untuk menarik kesimpulan

Jenis kesalahan ini ialah kesalahan yang biasa dilakukan siswa pada saat menarik kesimpulan dari suatu masalah yang diberikan.

4) Kesalahan menggunakan definisi atau teorema

Kesalahan ini biasa dilakukan siswa pada saat menyelesaikan permasalahan yang dituntut menggunakan rumus, teorema, prinsip, ataupun definisi matematika. Siswa melakukan kesalahan ketika menggunakan rumus ataupun teorema yang tidak sesuai dengan permasalahan.

5) Penyelesaian tidak diperiksa kembali

Jenis kesalahan ini terjadi jika setiap langkah penyelesaian yang dilakukan oleh siswa tidak sesuai dengan hasil akhir. Jenis kesalahan ini terjadi ketika siswa mengerjakan soal secara terburu-buru sehingga pekerjaannya tidak dikoreksi kembali.

6) Kesalahan teknis

Kesalahan teknis yang mungkin terjadi ialah: (1) kesalahan perhitungan, (2) kesalahan dalam mengutip data, dan (3) kesalahan memanipulasi simbol-simbol. 
Beberapa penelitian telah menggunakan Kriteria Hadar untuk menganalisis kesalahan siswa. Laman (2019) dalam penelitiannya menunjukkan bahwa subjek yang mengerjakan soal HOTS melakukan kesalahan pada kriteria hadar yaitu kesalahan menggunakan logika dalam menarik kesimpulan, kesalahan menggunakan define atau teorema, dan kesalahan teknis.

Penelitian lainnya dikemukakan oleh Gusman (2021) dimana terdapat kesalahan hadar yang muncul yaitu kesalahan menggunakan data, kesalahan menggunakan logika untuk menarik kesimpulan, penyelesaian tidak diperiksa kembali dan kesalahan teknis. Kemudian sejalan dengan hasil penelitian Halim (2021) mengemukakan bahwa jenis kesalahan pada kriteria hadar yang dilakukan siswa adalah kesalahan menggunakan data, kesalahan menginterpretasi bahasa, kesalahan menggunakan logika untuk menarik kesimpulan, kesalahan menggunakan definisi ataupun teorema dan penyelesaian tidak diperiksa kembali.

\section{Research Methods}

Jenis penelitian ini adalah penelitian kualitatif dengan metodologi penelitian deskriptif. Penelitian ini dilaksanakan pada salah satu SMA di Kabupaten Majene, Sulawesi Barat. Subjek dalam penelitian ini terdiri dari 6 orang siswa yang dikelompokkan ke dalam masing-masing kategori pemahaman matematika yaitu 2 siswa dengan pemahaman matematika tinggi, 2 siswa dengan pemahaman matematika sedang, dan 2 siswa dengan pemahaman matematika rendah.

Pegambilan data dalam penelitian ini dimulai dengan melakukan tes pemahaman matematika kepada satu kelas XII kemudian mengelompokkan subjek yang termasuk dalam kategori pemahaman matematika tinggi, sedang dan rendah. Langkah selanjutnya memberikan tes masalah matematika materi barisan dan deret kepada subjek yang terpilih, setelah itu masing-masing subjek di wawancarai berdasarkan jawaban subjek pada tes masalah matematika. Data dari hasil tes masalah matematika dan wawancara kemudian di analisis sedangkan data pemahaman matematika siswa digunakan untuk mengetahui tingkat pemahaman matematika dari tiap siswa dalam menyelesaikan soal barisan dan deret.

\section{Results and Discussion}

Rincian masing-masing subjek yang dipilih disajikan dalam Tabel 1.

Tabel 1. Pengambilan Subjek Penelitian

\begin{tabular}{ccc}
\hline Kode Siswa & Kategori & Skor Tes \\
\hline S1 & Tinggi & 100 \\
S2 & Tinggi & 85.71 \\
S3 & Sedang & 71.43 \\
S4 & Sedang & 71.43 \\
S5 & Rendah & 14.29 \\
S6 & Rendah & 0 \\
\hline
\end{tabular}

\subsection{Kesalahan Subjek Pemahaman Matematika Tinggi}

Gambar 1 terlihat bahwa subjek melakukan kesalahan dalam penulisan lambang tambah dan kurang (S1-T22, S1T23). Pada langkah tersebut, subjek keliru dalam melakukan operasi, dimana hasil dari $(n-1) 25$ setelah dioperasikan subjek menuliskan hasilnya menjadi $25 n+25$ yang seharusnya $25 n-25$.

Berikut petikan wawancara subjek terkait jawaban di atas mengenai kesalahan teknis pada Transkrip 1:

\section{Transkrip 1}

$P$

S1-W210 Astaga waduh salah tulis ka kak, seharusnya tanda minus disitu bukan plus

$P \quad$ Ini juga dek, masa 1600+25 hasilnya 1575, ditaumi toh letak kekeliruan nya?

S1-W211 Hehehe iye kak salah tulis $\mathrm{ka}$ 


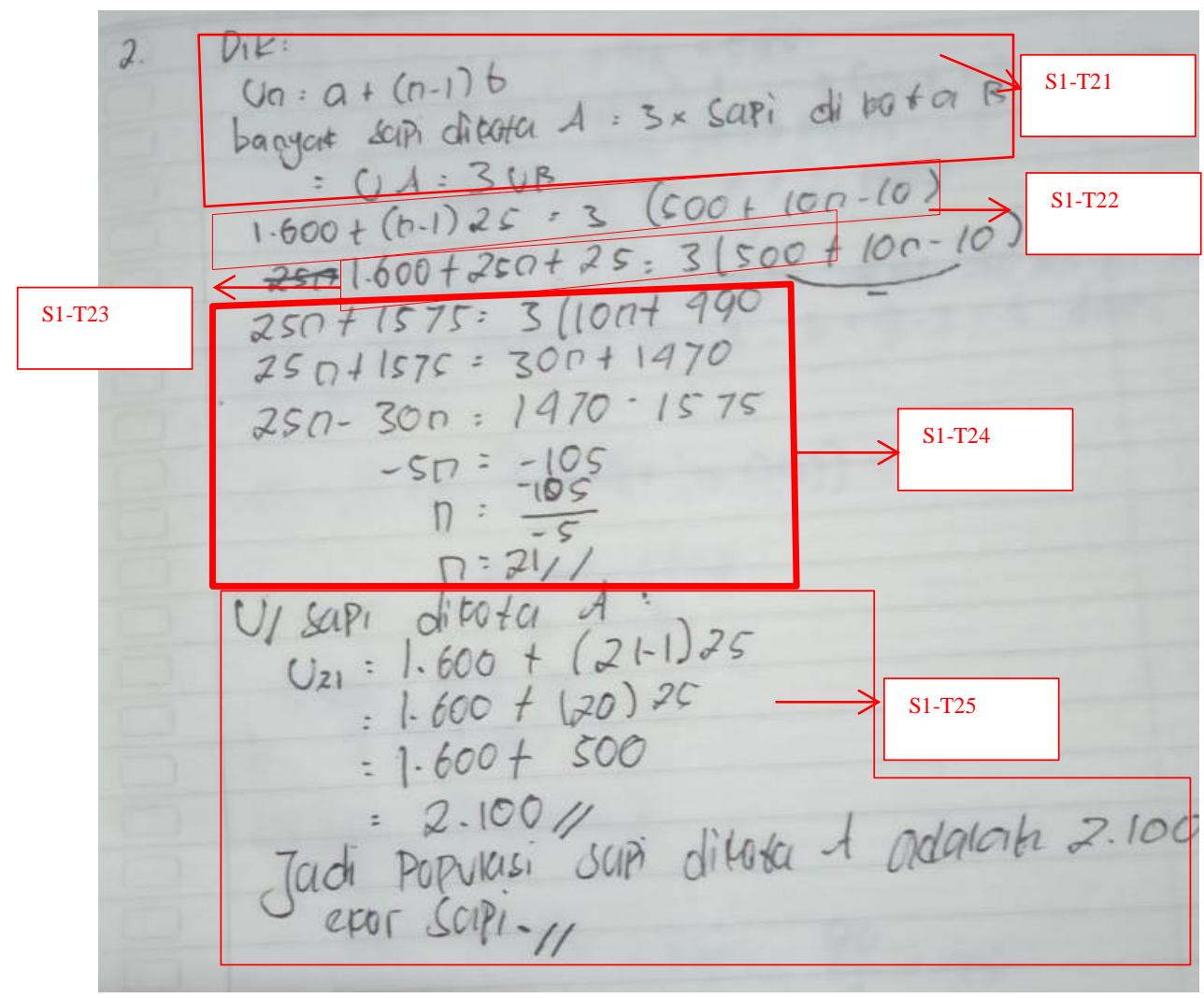

Gambar 1. Jawaban S1

Transkrip 1 terlihat bahwa ketika dikonfirmasi terkait dengan jawabannya, subjek baru menyadari dan memahami bahwa subjek telah melakukan kesalahan dalam menuliskan lambang tambah dan kurang pada jawabannya (S1W210). Sehingga dapat disimpulkan bahwa pada data jawaban (S1-T22,W1-T23) terdapat kesalahan teknis.

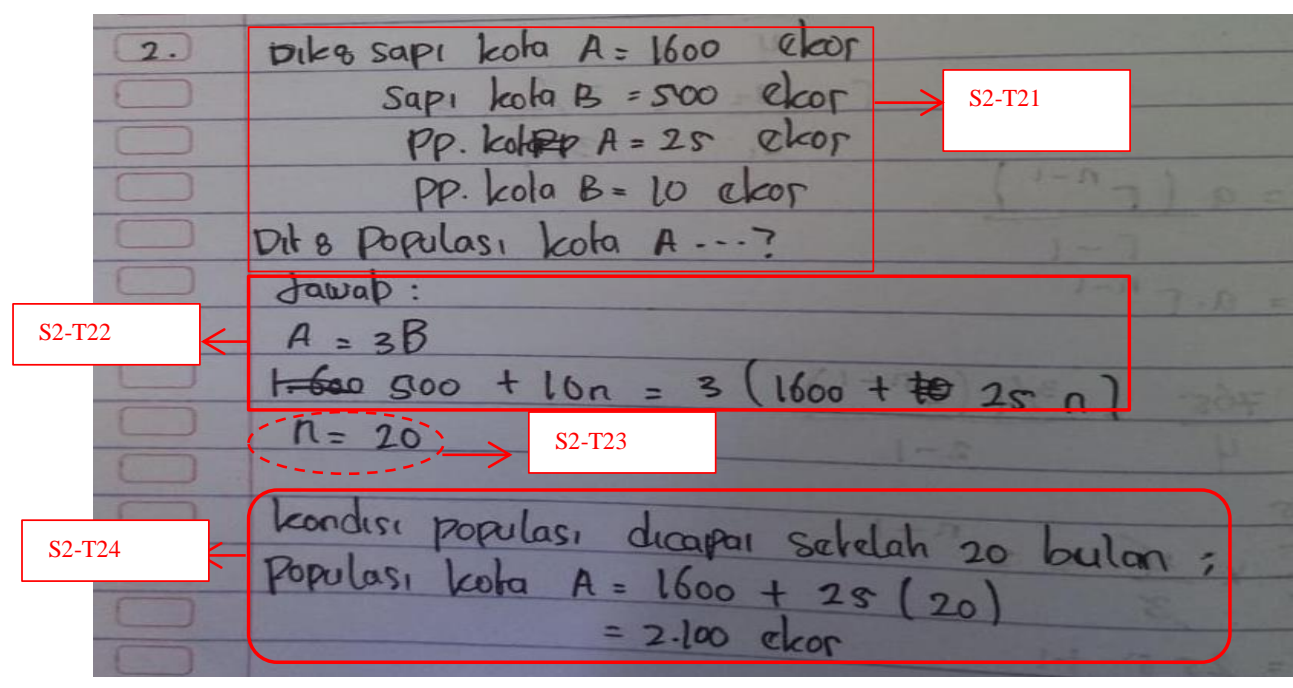

Gambar 2. Jawaban S2 
Gambar 2 terlihat bahwa subjek melakukan kesalahan perhitungan (S2-T22,S2-T23). Subjek mengoperasikan $900+10 n=3(1600+25 n)$ dan mendapatkan nilai $n=20$. Akan tetapi, jika dioperasikan dengan baik, nilai $n$ nya akan sama dengan 60 , bukan 20

Berikut petikan wawancara subjek terkait jawaban di atas mengenai kesalahan teknis pada Transkrip 2:

\section{Transkrip 2}
$P$
$S 2-W 218$
S2-W219
$S 2-W 220$
Jadi dek, kekeliruanta sedikit itu ada di 1600+25n dan 500+10n
Seharusnya itu dek $1600+(n-1) 25$ dan $500+(n-1) 10$
Iyye kak lupaka
Cobaki selesaikan ulang ini dek $(500+10 n=3(1600+25 n))$ pasti nilainya $n$ nya bukan $n=20$
Iyye kak hehe

Transkrip 2 menunjukkan bahwa subjek telah melakukan kesalahan perhitungan dan kekeliruan dalam menentukan penyelesaian yang tepat. Berdasarkan data jawaban subjek (S2-T22) dan petikan wawancara (S2-W220) menunjukkan bahwa pada data tersebut terdapat kesalahan teknis.

\subsection{Kesalahan Subjek Pemahaman Matematika Sedang}

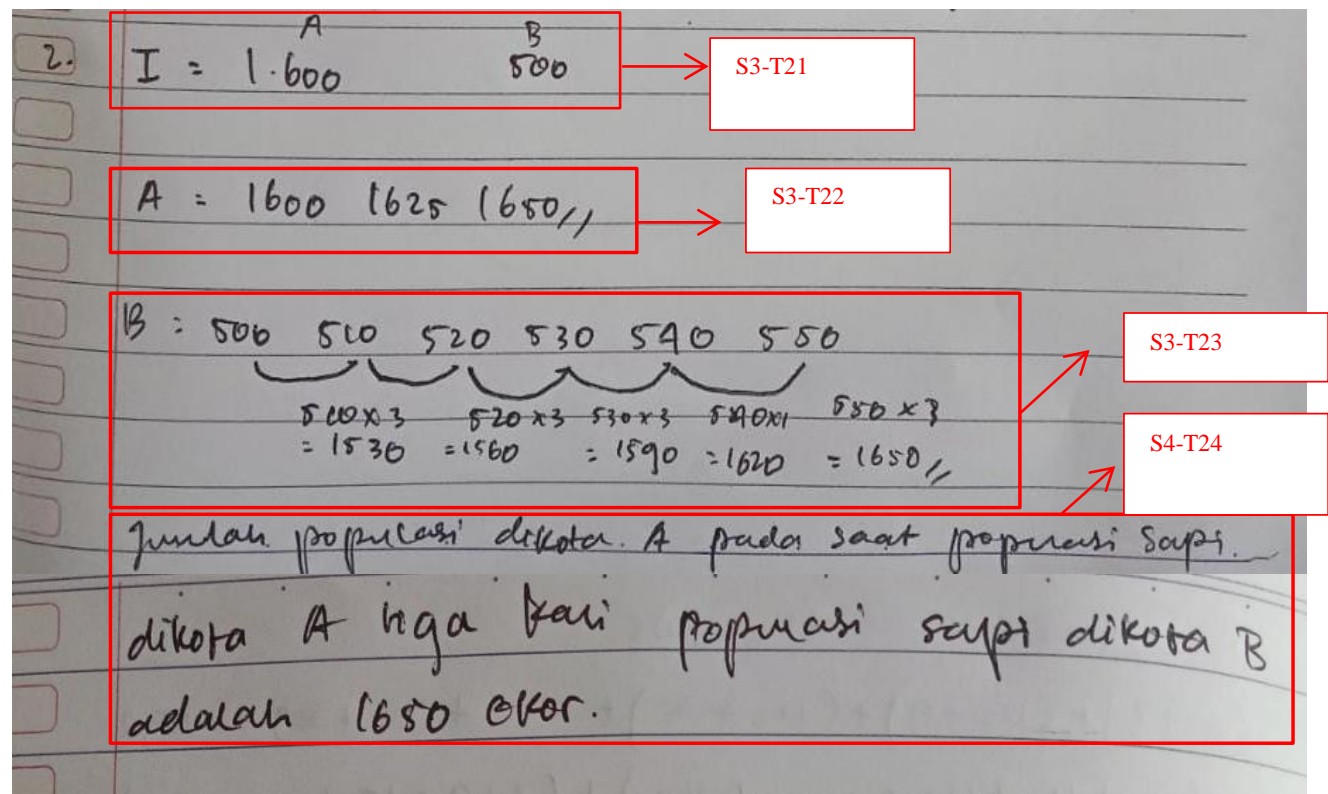

Gambar 3. Jawaban S3

Gambar 3 terlihat bahwa subjek melakukan kesalahan dalam mengutip data dan menggunakan simbol-simbol yang keliru (S3T21-S3-T23). Subjek mula-mula menuliskan model dan simbol matematika I = 1600(A) 500(B). Kemudian subjek menuliskan $A=160016251650$ dimana subjek tidak menuliskan simbol yang tepat untuk mengerjakan soal. Yang seharusnya $\mathrm{Un}=1600+(\mathrm{n}-1) 25$

Berikut petikan wawancara subjek terkait jawaban di atas mengenai kesalahan teknis pada Transkrip 3 :

\section{Transkrip 3}

$P$

S3-W216

$P$

Yakin miki dek dengan jawabanta?

Ya begitu kak, nda terlalu

Kira-kira carata ini kerja benarmi dirasa perhitungannya?

S3-W217 Kalau menurutku ada mungkin salah kak 
Transkrip 3, menunjukkan bahwa subjek ragu akan jawabannya dan tidak terlalu yakin apakah pekerjaannya sudah benar atau belum. Berdasarkan data jawaban (S3-T21-S3-T23) dan petikan wawancara (S3-W217) menunjukkan bahwa pada data tersebut terdapat kesalahan teknis.

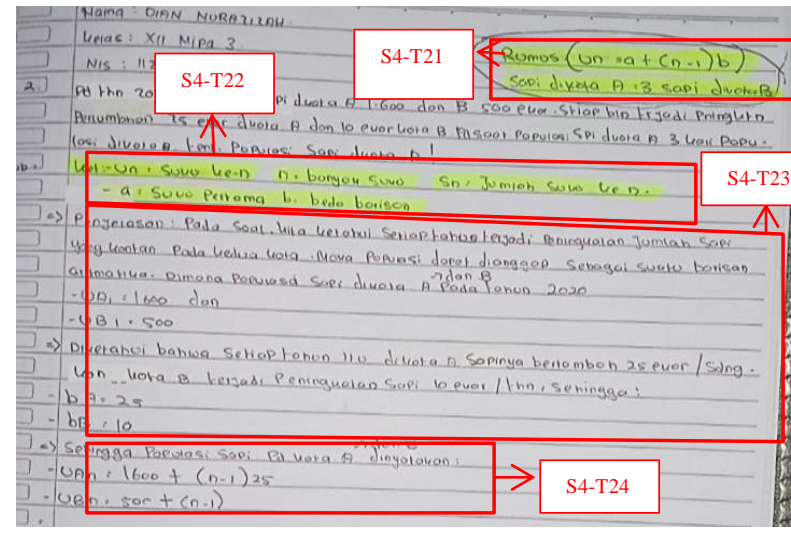

(a)

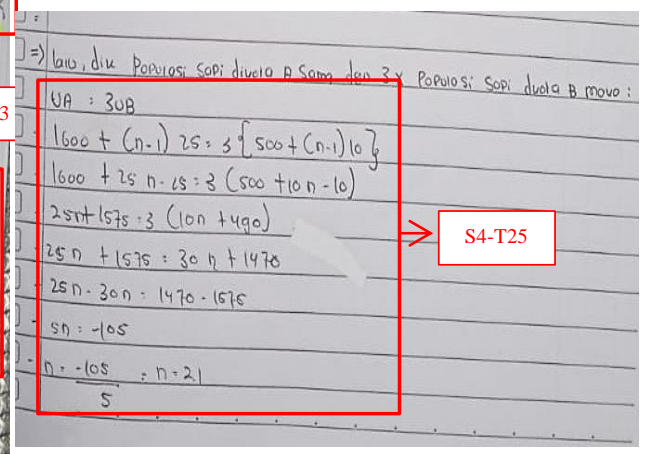

(b)

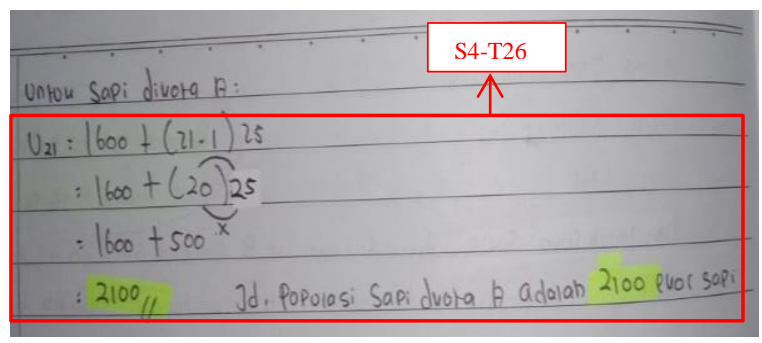

Gambar 4. Jawaban S4

Gambar 4 terlihat bahwa subjek kurang teliti dalam memperhatikan langkah-langkah penyelesaiannya. Subjek sudah benar dalam menuliskan $\mathrm{UA}_{\mathrm{n}}=1600+(\mathrm{n}-1) 25$ namun untuk $\mathrm{UB}_{\mathrm{n}}$, subjek kurang teliti sehingga menuliskan $\mathrm{UB}_{\mathrm{n}}=$ $500+(\mathrm{n}-1)$ yang seharusnya $\mathrm{UB}_{\mathrm{n}}=500+(\mathrm{n}-1) 10$

Berikut petikan wawancara subjek terkait jawaban di atas mengenai kesalahan teknis pada Transkrip 4:

\section{Transkrip 4}

$P \quad$ Dek, nda adaji kita liat perbedaan ini yang $U B n=500+(n-1)$ sama yang dibawahnya $3\{500+$ (n-1)10\} (mengirimkan screenshoot lembar kerja subjek yang sudah ditandai peneliti)?

S4-W211 Astaga iya kak, lupaka itu di atasnya, buru-buru kak jadi nda kuliat padahal sudahmi kucek baikbaik.

Transkrip 4, menunjukkan bahwa subjek mengakui bahwa ia lupa menuliskan persamaan yang tepat karena terburuburu. Berdasarkan data jawaban (S4-T24) dan petikan wawancara (S4-W211) menunjukkan pada data tersebut terdapat kesalahan teknis.

\subsection{Kesalahan Subjek Pemahaman Matematika Rendah}

Gambar 5, terlihat bahwa subjek tidak menuliskan semua informasi yang dibutuhkan untuk mengerjakan soal dan tidak menuliskan apa yang ditanyakan dari soal tetapi subjek langsung mengerjakannya (S5-T21). Subjek tidak menuliskan data-data apa saja yang diperlukan dalam soal dengan baik dan tidak membuat model matematika yang tepat.

Berikut petikan wawancara yang berkaitan dengan kesalahan menggunakan data pada Transkrip 5 : 


\section{Transkrip 5}

$P$

Untuk soal nomor 2, informasi apa yang kita dapat setelah dibaca soalnya dek?

S5-W21 Nah kan di soal nabilang di kota $A=1600$ ekor, di kota B $=500$ ekor. Terus nabilang lagi terjadi pertumbuhan 25 ekor A dan 10 ekor di B. Nah yang tanyakan, berapa populasi di kota A kalau tiga kali populasi di kota $B$

$P \quad \quad$ Kenapa tidak kita tulis di lembar jawabanta dek?

S5-W22 Kutulisji itu kak A 1600 sama B 500

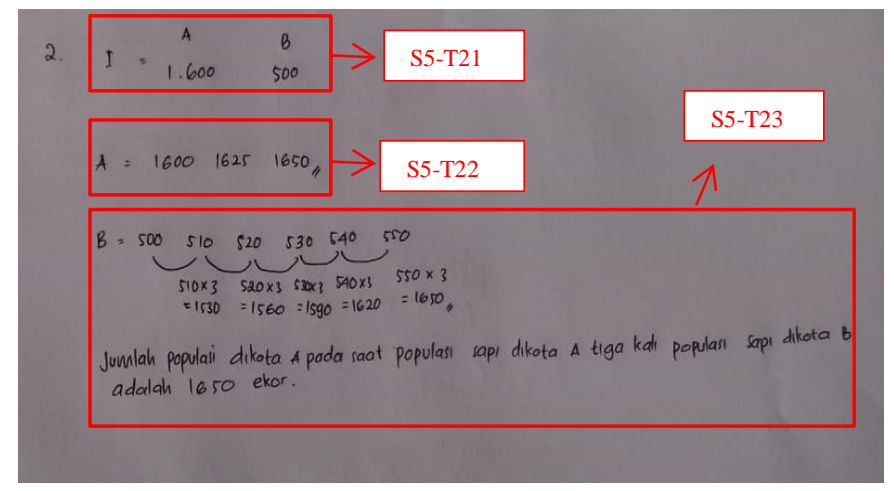

Gambar 5. Jawaban S5

Pada Transkrip 5, terlihat bahwa subjek mampu mengetahui informasi dan apa yang ditanyakan dari soal tetapi subjek kemudian keliru dalam menentukan proses penyelesaiannya. Berdasarkan data jawaban (S5-T21) dan petikan wawancara (S5-W22) menunjukkan bahwa pada data tersebut terdapat kesalahan dalam menggunakan data.

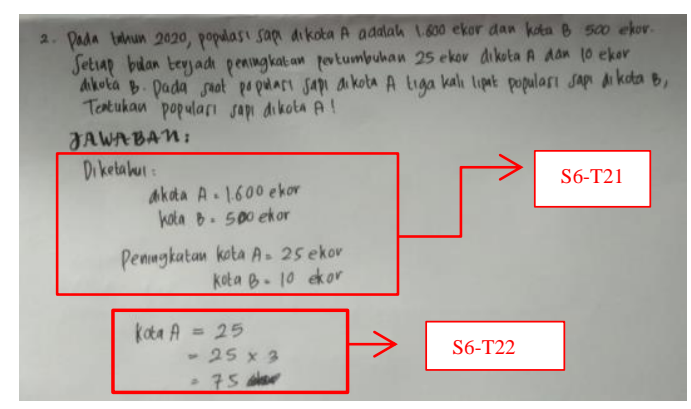

Gambar 6. Jawaban S6

Gambar 6, terlihat bahwa subjek mampu menuliskan informasi dari soal dengan baik namun subjek tidak menuliskan apa yang ditanyakan dari soal tetapi subjek langsung mengerjakannya (S6-T21).

Berikut petikan wawancara terkait dengan kesalahan menggunakan data pada Transkrip 6 :

\section{Transkrip 6}

P Untuk nomor 2, pas ki baca soalnya informasi apa yang kita dapat dek?

S6-W21 Sapi di kota $A=1600$ ekor, sapi di kota $B=500$ ekor. Ada peningkatan tiap bulan sapi kota $A=$ 25 ekor, sapi di kota $B=10$ ekor

$P \quad$ Terus dek?

S6-W22 Ditanya berapa sapi di kota A pada saat sapi di kota A tiga kali sapi di kota B

$P \quad$ Kenapa tidak kita tulis di lembar jawabanta?

S6-W23 Tidak kutulis yang ditanya kak karena biasa yang kutulis diketahuinya saja 
Pada Transkrip 6, terlihat bahwa subjek mampu mengetahui dan menuliskan informasi dari soal namun tidak menuliskan apa yang ditanyakan dari soal. Subjek mengabaikan data yang diberikan. Berdasarkan data jawaban (S6T21) dan petikan wawancara subjek (S6-W23) menunjukkan pada data tersebut terdapat kesalahan dalam menggunakan data.

\section{Conclusion}

Semua subjek dalam mengerjakan soal nomor satu yang berkaitan dengan mencari nilai suku ke-P pada deret geometri dan pada saat mengerjakan soal nomor dua yang berkaitan dengan menentukan populasi sapi, subjek cenderung melakukan kesalahan teknis. Sedangkan dalam mengerjakan soal nomor tiga yang berkaitan dengan menentukan jumlah suku-suku pada suatu barisan aritmatika, subjek dengan pemahaman matematika tinggi dan sedang sama sekali tidak mengalami kesalahan dalam menyelesaikan jawabannya kecuali subjek dengan pemahaman matematika rendah yang tidak menjawab sama sekali.

\section{References}

Anwar, Z., \& Hidayani. (2020). Analisis kesalahan siswa smp kelas viii dalam menyelesaikan soal lingkaran. Mercumatika : Jurnal Penelitian Matematika dan Pendidikan Matematika.

Departemen Pendidikan Nasional. 2006. Permendiknas No 22 Tahun 2006 tentang Standar Isi. Jakarta : Depdiknas

Elizabeth, A.C. (2016). Analisis kesalahan dalam menyelesaikan soal geometri ruang pada siswa kelas x sma marsudirini muntilan tahun ajaran 2014/2015. Skripsi. Yogyakarta : Universitas Sanata Dharma.

Gusman, R.Z. (2021). Analisis kesalahan siswa dalam menyelesaikan soal pemahaman konsep matematika berdasarkan kriteria hadar ditinjau dari kemampuan awal siswa. Skripsi. STKIP PGRI Sumatera Barat.

Hadar, M., Zaslavsky, O., \& Inbar, S. (1987). An Empirical Classification Model For Error in High School Mathematics.18(1).

Halim, N.H. (2021). Analisis kesalahan siswa dalam menyelesaikan soal matematika berbasis HOTS materi pola bilangan berdasarkan kriteria hadar. Skripsi. Makassar. Universitas Muhammadiyah Makassar.

Handayani, T. (2020). Analisis kesalahan siswa dalam menyelesaikan soal cerita materi barisan dan deret aritmatika. Skripsi. Universitas Islam Negeri Raden Fatah Palembang.

Laman, G. E. (2019). Analisis kesalahan siswa dalam memecahkan masalah matematika higher order thinking skills (hots) berdasarkan kriteria hadar ditinjau dari kemampuan awal siswa kelas xii sman 5 makassar. Skripsi. Makassar : Universitas Negeri Makassar.

Nurfahmi, N. (2018). Analisis kesalahan siswa dalam menyelesaikan soal cerita matematika pada materi barisan dan deret aritmetika. Skripsi. Makassar : Universitas Negeri Makassar.

Rahmawati, A. (2018). Analisis kesalahan mahasiswa Pendidikan matematika dalam menyelesaikan soal pertidaksamaan pada mata kuliah kalkulus I. Journal of Chemical Information and Modeling.

Widyatari, R. (2017). Analisis kesalahan siswa dalam menyelesaikan soal barisan dan deret ditinjau dari komunikasi matematika. (Skripsi tidak dipublikasikan). Universitas Muhammadiyah, Surakarta. 